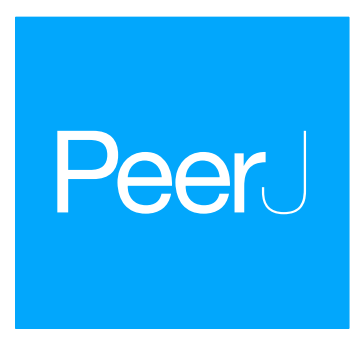

Submitted 10 June 2017

Accepted 5 January 2018

Published 15 February 2018

Corresponding authors

José F. Domínguez-Contreras,

fradoco@gmail.com

Adrian Munguia-Vega,

airdrian@email.arizona.edu

Academic editor

Robert Toonen

Additional Information and Declarations can be found on page 18

DOI 10.7717/peerj.4295

Distributed under Creative Commons Public Domain Dedication

OPEN ACCESS

\section{Life histories predict genetic diversity and population structure within three species of octopus targeted by small-scale fisheries in Northwest Mexico}

\author{
José F. Domínguez-Contreras ${ }^{1,2}$, Adrian Munguia-Vega ${ }^{3,4}$, \\ Bertha P. Ceballos-Vázquez ${ }^{2}$, Marcial Arellano-Martínez ${ }^{2}$, \\ Francisco J. García-Rodríguez ${ }^{2}$, Melanie Culver ${ }^{3,5}$ and Hector Reyes-Bonilla ${ }^{1}$ \\ ${ }^{1}$ Departamento Académico de Ciencias Marinas y Costeras, Universidad Autónoma de Baja California Sur, \\ La Paz, Baja California Sur, Mexico \\ ${ }^{2}$ Instituto Politécnico Nacional, Centro Interdisciplinario de Ciencias Marinas, La Paz, Baja California Sur, \\ Mexico \\ ${ }^{3}$ Conservation Genetics Laboratory, School of Natural Resources and Environment, University of Arizona, \\ Tucson, AZ, United States of America \\ ${ }^{4}$ Comunidad y Biodiversidad A. C., Guaymas, Sonora, Mexico \\ ${ }^{5}$ U.S. Geological Survey, Arizona Cooperative Fish and Wildlife Research Unit, School of Natural Resources \& \\ Environment, University of Arizona, Tucson, AZ, United States of America
}

\section{ABSTRACT}

The fishery for octopus in Northwest Mexico has increased to over 2,000 tons annually, but to date the specific composition of the catch has been ignored. With at least three main species targeted by artisanal fisheries in the region with distinct life histories, the lack of basic biological information about the distribution, metapopulation size and structure of each species could impede effective fisheries management to avoid overexploitation. We tested if different life histories of three species of octopus could help predict observed patterns of genetic diversity, population dynamics, structure and connectivity and how this information could be relevant to the sustainable management of the fishery. We sequenced two mitochondrial genes and genotyped seven nuclear microsatellite loci to identify the distribution of each species in 20 locations from the Gulf of California and the west coast of the Baja California peninsula. We tested five hypotheses derived from population genetic theory based on differences in the fecundity and dispersal potential for each species. We discovered that Octopus bimaculoides with low fecundity and direct development (without a planktonic phase) had lower average effective population size and genetic diversity, but higher levels of kinship, population structure, and richness of private alleles, than the other two species. These features indicated limited dispersal and high local recruitment. In contrast, O. bimaculatus and O.hubbsorum with higher fecundity and planktonic phase as paralarvae had higher effective population size and genetic diversity, and overall lower kinship and population structure than O. bimaculoides. These observations supported higher levels of gene flow over a larger geographical scale. O. bimaculatus with the longest planktonic paralarval duration and therefore larger dispersal potential had differences in the calculated parameters possibly associated with increased connectivity. We propose O. bimaculoides is more susceptible to over exploitation of small, isolated populations and could have longer recovery times than the other two species. This species may 
benefit from distinct fishery management within each local population. O. bimaculatus and O. hubbsorum may benefit from fishery management that takes into account metapopulation structure over larger geographic scales and the directionality and magnitude of larval dispersal driven by ocean currents and population connectivity among individuals of each locality. The distribution of each species and variations in their reproductive phenology is also important to consider when establishing marine reserves or seasonal fishing closures.

Subjects Aquaculture, Fisheries and Fish Science, Conservation Biology, Genetics, Marine Biology, Natural Resource Management

Keywords Octopus, Fecundity, Planktonic paralarval duration, Paralarval dispersal, Marine connectivity, Gulf of California

\section{INTRODUCTION}

As fish catches are collapsing around the world, the focus of commercial fisheries has shifted to resources within lower trophic levels, but with similar or higher economic revenues (Pauly et al., 2002; Sala et al., 2004; Watson \& Pauly, 2001). Cephalopods are a marine resource with lower trophic levels capable of supporting the substantial expansion of fisheries landings (Arkhipkin et al., 2015; Doubleday et al., 2016). Therefore fishing pressure is expected to increase in the near future as a response to growing demands of marine resources associated with increase of global human population (Hunsicker et al., 2010). Cephalopods account for about $20 \%$ of the fisheries landing in the world, mainly comprised of squids (FAO, 2015). Octopus catches targeted by small-scale fisheries have increased considerably from 1970 ( 3,000 ton/year) to 2017 ( 60,000 ton/year) and its commercial value is sometimes higher than squids (FAO, 2015). During 2003-2013 most of the global production (80\%) was caught in Mexico (36\%), Spain (17\%), Portugal (15\%), Italy (12\%) (FAO, 2015). In Mexico O. maya (Voss \& Solís-Ramirez, 1966) is the most economically important species captured along the Atlantic coast (NOM-008-PESC-1993; Jurado-Molina, 2010).

At least 10 different octopus species have been described in the Mexican Pacific, including O. bimaculatus (Verrill, 1883), O. chierchiae (Jatta, 1889), O. digueti (Perrier \& Rochebrune, 1894), O. bimaculoides (Pickford \& MacConnaughey, 1949), and Berry's (1953) octopuses: O. alecto, O. fitchi, O. hubbsorum, O. veligero, O. rubescens and O. penicillifer (Brusca, 1980; Gotshall, 1998; Hochberg \& Fields, 1980; Norman \& Hochberg, 2005; Roper, Sweeney \& Hochberg, 1995). Recent studies indicate that likely three species contribute most of the catch volume in the Pacific coast of Mexico, namely O. hubbsorum (AlejoPlata et al., 2009; Dominguez-Contreras et al., 2013; López-Uriarte, Ríos-Jara \& Pérez-Peña, 2005), O. bimaculatus (López-Rocha et al., 2012; Villegas et al., 2014), and O. bimaculoides (González-Meléndez, 2012). In Northwest Mexico, the octopus fishery represents an important income for small-scale fishers that sell the catch locally or in commercial markets (Finkbeiner, 2015; Finkbeiner \& Basurto, 2015; Moreno-Báez et al., 2012). However, it still unclear which species contribute to the catch in different localities because official fishery 
statistics do not attempt to distinguish different species. During 2014, official reports indicate that artisanal fishery operating along Norwest Mexico produced at least $\sim 2,000$ tons of octopus worth $\sim 350,000$ USD (CONAPESCA, 2014). Most capture of octopus in this region takes place in the Gulf of California year-round via hooka diving with an air compressor or using traps. In the past, it was suggested that the fishery might be targeting at least two different species (O. bimaculatus and O. hubbsorum) (Moreno-Báez et al., 2012). The lack of species identification in octopus fisheries reports is due to their dynamic biological behavior and ability to change color, pattern, texture and shape (Boyle $\&$ Von Boletzky, 1996). In addition, their anatomy includes few hard structures that makes the species identification to the species level difficult for fishermen and fishery managers, especially in octopods (Hanlon, 1988).

Ignoring which species are being fished, and their geographic distribution, could have serious detrimental consequences in the long-term, not only for local fisheries management but for the conservation of the species (Garcia-Vazquez et al., 2012). For example, without precise fishery monitoring, it could be impossible to estimate if a particular species or stock is being over or under exploited in a certain area (Marko et al., 2004). The problem of not identifying each species could be particularly serious if octopuses show contrasting life histories and population dynamics that may translate into distinct levels of maximum sustainable yield (MSY) and recovery times. Different life histories may require distinct management strategies during different seasons and over differing geographic scales. O. bimaculatus could potentially be sympatric with O. bimaculoides in the west coast of the Baja California peninsula, while O. bimaculatus could potentially overlap its geographic distribution with O. hubbsorum in the Gulf of California (Table 1). The reproductive season is different for each species, and the three species differ in their fecundity, egg size and planktonic paralarval duration (PPD) (Table 1). Octopus bimaculoides spawns hundreds of large eggs and lacks a paralarval stages and therefore does not pass through a planktonic phase. O. hubbsorum lays thousands of smaller-sized eggs and the PPD is probably similar to O. vulgaris based on the size of its eggs ( $\sim 60$ days, Iglesias et al., 2007). O. bimaculatus lays thousands of medium-sized eggs and shows a relatively longer PPD (up to 90 days) than O. hubbsorum and O. bimaculoides (Table 1). The three species have life spans lasting between 1.5 and two years and males typically have smaller size at sexual maturity than females (Table 1).

Our main hypothesis is that differences in the life history among the three octopus species from Northwest Mexico could translate into distinct patterns of genetic diversity, population dynamics, structure and larval connectivity relevant for sustainable fisheries management. We used two mitochondrial DNA markers and seven nuclear microsatellite loci, informative for the three species, to infer relevant differences in population parameters and evolutionary processes among species. We first established the geographic distribution of each species through genetic identification of tissue samples collected over the study area. Later, five a priori hypotheses were tested based on the fecundity and potential for paralarval dispersal reported in the scientific literature for each species derived from theoretical and empirical population genetic studies regarding expected effective population size, genetic diversity, genetic relatedness within populations (kinship) and population 
Table 1 Life history. Life history of three species of octopus from Northwest Mexico.

\begin{tabular}{|c|c|c|c|c|}
\hline Life history & O. bimaculoides & O. hubbsorum & O. bimaculatus & References \\
\hline $\begin{array}{l}\text { Geographic } \\
\text { distribution }\end{array}$ & $\begin{array}{l}\text { From CA, USA to Bahia } \\
\text { San Quintin in BC, } \\
\text { Mexico. }\end{array}$ & $\begin{array}{l}\text { From Bahia Magdalena, } \\
\text { BCS to Oaxaca, including } \\
\text { the Gulf of California. }\end{array}$ & $\begin{array}{l}\text { From CA, USA to Bahia } \\
\text { Vizcaino BCS, including the } \\
\text { Gulf of California }\end{array}$ & $(2,3,4$ and 10$)$ \\
\hline $\begin{array}{l}\text { Reproductive } \\
\text { period }\end{array}$ & $\begin{array}{l}\text { Santa Barbara, CA, } \\
\text { USA (Dec-May) } \\
\text { San Quintin, BCP, Mexico } \\
\text { (Oct-Jan) }\end{array}$ & $\begin{array}{l}\text { Pacific coast of BCP } \\
\text { (May-Oct) } \\
\text { Gulf of California } \\
\text { (Mar, Sep-Dec) }\end{array}$ & $\begin{array}{l}\text { Pacific coast of BCP } \\
\text { (Jan-Jun) } \\
\text { Gulf of California } \\
\text { (Jun-Sep) }\end{array}$ & $(1,2,3,5$, and 8$)$ \\
\hline${ }^{a}$ Fecundity & $\begin{array}{l}\text { Eggs laid in festoons } \\
137-780\end{array}$ & $\begin{array}{l}\text { Clutch eggs } \\
105,000-144,000 \\
\text { Ripe ovarian eggs } \\
240,050 \\
\text { (range } 22,447-545,444)\end{array}$ & $\begin{array}{l}\text { Clutch eggs } \\
>20,000 \\
\text { Ripe ovarian eggs } \\
91,407 \pm 75,361 \mathrm{SD} \\
(\text { range } 11,618-372,269)\end{array}$ & $(1,2,6,9,11$ and 12$)$ \\
\hline $\begin{array}{l}{ }^{a} \text { Egg size (length) } \\
\text { and ripe ovarian } \\
\text { eggs size }\end{array}$ & $\begin{array}{l}10-12 \mathrm{~mm} \\
(\text { range } 9.5-16 \mathrm{~mm})\end{array}$ & $\begin{array}{l}1.66 \pm 0.74 \mathrm{~mm} \\
\text { Ripe ovarian eggs } 2.07 \mathrm{~mm} \\
(\text { range } 0.7-3.7 \mathrm{~mm})\end{array}$ & $\begin{array}{l}4-7 \mathrm{~mm} \\
\text { Ripe ovarian eggs } \\
\text { (range } 1.8-4 \mathrm{~mm} \text { ) }\end{array}$ & $(1,2,3,9,11$, and 12$)$ \\
\hline $\begin{array}{l}\text { Planktonic larval } \\
\text { duration } \\
\text { (paralarvae) }\end{array}$ & $\begin{array}{l}\text { Absent, direct development to } \\
\text { juvenile, benthic hatchlings }\end{array}$ & $\begin{array}{l}\text { Present but the time is uncertain } \\
\text { (Probably } \sim 60 \text { days) }\end{array}$ & $2-3$ months (60 to 90 days) & $(1,2,3$, and 11$)$ \\
\hline $\begin{array}{l}\text { Size at sexual } \\
\text { maturity }\end{array}$ & $\begin{array}{l}55 \mathrm{~mm}(\mathrm{ML}) \text { males } \\
110 \mathrm{~mm}(\mathrm{ML}) \text { females }\end{array}$ & $\begin{array}{l}70 \mathrm{~mm}(\mathrm{ML}) \text { males } \\
119.7 \mathrm{~mm}(\mathrm{ML}) \text { females }\end{array}$ & $\begin{array}{l}124.5 \mathrm{~mm}(\mathrm{ML}) \text { males } \\
147.0 \mathrm{~mm}(\mathrm{ML}) \text { females }\end{array}$ & $(2,6,8$, and 12$)$ \\
\hline Lifespan (years) & Short (1.0-1.5) & Short (1.5) & Short (1.5-2.0) & $(2,3$, and 6$)$ \\
\hline
\end{tabular}

Notes.

${ }^{a}$ considering average, min and max reported value. (1) Ambrose (1981), (2) Forsythe \& Hanlon (1988a), Forsythe \& Hanlon (1988b) (3) Ambrose (1990), (4) López-Uriarte, RíosJara \& Pérez-Peña (2005), (5) Castellanos-Martínez (2008), (6) López-Uriarte \& Rios-Jara (2009), (8) Dominguez-Contreras (2011), (9) Cardenas-Robles (2013), (10) DominguezContreras et al. (2013), (11) Alejo-Plata \& Herrero-Alejo (2014) and (12) Alejo-Plata \& Gómez-Márquez (2015).

BCP, Baja California Peninsula; ML, Mantle Length.

structure (Tables 1 and 2). We discuss implications of our results for fisheries management of the three species in Northwest Mexico.

\section{MATERIALS \& METHODS}

\section{Sample collection and DNA extraction}

We obtained 316 tissue samples of octopus (arm tissue) collected between 2008 and 2013 from 20 localities in both coasts of the Baja California peninsula, including the Northeast coast of the Gulf of California (Field experiments were approved by Secretaría de Agricultura, Ganadería, Desarrollo Rural, Pesca y Alimentación, SAGARPA No. PPF/DGOPA.09151.260809.2885 and PPF/DGOPA-224/16) (Fig. 1). The field sampling took place mainly during spring and summer (Table S1) at fishing communities with 
Table 2 Hypotheses. Hypotheses regarding levels of genetic diversity and structure based on the life history of three species of octopus from Northwest Mexico.

\begin{tabular}{|c|c|c|c|c|}
\hline Hypotheses & O. bimaculoides & O. hubbsorum & O. bimaculatus & References \\
\hline Effective population size $\left(N_{e}\right)$ & Small & Medium & Large & (1 and 2$)$ \\
\hline Genetic diversity (allelic richness) $\left(N_{E}, R_{A}\right)$ & Low & Medium & High & (1 and 2) \\
\hline Diversity of private alleles $\left(R_{P A}\right)$ & High & Medium & Low & (3 and 4$)$ \\
\hline Genetic structure $\left(F_{S T}\right)$ & High & Medium & Low & $(5,6$, and 7$)$ \\
\hline Genetic relatedness $(\mathrm{R})$ & High & Medium & Low & (8 and 9$)$ \\
\hline
\end{tabular}

Notes.

(1) Romiguier et al. (2014), (2) Ellegren « Galtier (2016), (3) Beger et al. (2014), (4) Munguía-Vega et al. (2015), (5) Selkoe \& Toonen (2011), (6) Riginos \& Liggins (2013), (7) Selkoe et al. (2014), (8) Christie et al. (2010), (9) Burgess et al. (2014).

the help of small-scale fishers. Octopuses were collected at seven locations along the west coast of the Baja California peninsula, (Ejido Erendira close to Ensenada, Baja California down to El Conejo in Baja California Sur) and 13 sites from the central (Santa Rosalía) and northern Gulf of California (from the northern tip of Bahía de Los Angeles and Isla Tiburón up to Puerto Peñasco), including the Midriff islands. The Midriff islands include many islands and islets in the northern Gulf of California (Fig. 1). Several locations are remote and with difficult access, therefore had smaller samples sizes, while others localities with low number of samples was due to the difficulty of catching octopuses outside their reproductive season. We distinguished between O. bimaculatus and O. bimaculoides based on distinctive characteristics of the gonads of mature females using criteria described by Pickford \& MacConnaughey (1949). O. hubbsorum was identified using morphological traits described by Dominguez-Contreras et al. (2013); and original descriptions of Berry (1953). Tissue samples were stored in $96 \%$ ethanol in the field and $-20{ }^{\circ} \mathrm{C}$ in the lab. We extracted DNA using the DNeasy blood and tissue kit (QIAGEN, Valencia, CA, US) following the manufacturer specifications.

\section{Mitochondrial DNA sequencing}

We amplified two fragments of mitochondrial genes for a subset of the samples to detect the presence of each species at representative locations and to control for the differential success of cross-amplifying microsatellite loci (see below). We selected 97 individuals from 13 localities, including 8 individuals per locality except for Puerto Refugio which had one sample analyzed. We targeted the large ribosomal subunit rRNA (16S) gene employing primers L1987 5'GCCTCGCCTGTTTACCAAAAAC-3' and H2609 5'-CGGTCTGAACTCAGATCACGT$3^{\prime}$ (Palumbi et al., 1991) and the Cytochrome Oxidase subunit 1 (COI) gene with primers LCO 1490 5'-GGTCAAACAAATCATAAAGATATTGG-3'and HCO2198 5'TAAAATTCAGGGTGACCAAAAAATCA-3'(Folmer et al., 1994). We used $25 \mu \mathrm{L}$ volume PCRs reactions with 15-40 ng genomic DNA, $1 \times$ PCR buffer, $0.2 \mathrm{mM}$ each dNTP, $2 \mathrm{mM}$ $\mathrm{MgCl}_{2}, 0.2 \%$ BSA, $1 \mathrm{U}$ Taq DNA polymerase (Invitrogen, Carlsbad, CA, USA) and $0.5 \mu \mathrm{M}$ of each primer for both markers. PCR thermo-cycling consisted of denaturation at $94{ }^{\circ} \mathrm{C}$ for $2 \mathrm{~min}, 30$ cycles of $94^{\circ} \mathrm{C}$ for $1 \mathrm{~min}$, annealing at $51^{\circ} \mathrm{C}(\mathrm{COI})$ or $45.5^{\circ} \mathrm{C}(16 \mathrm{~s} \mathrm{rDNA})$ for $1 \mathrm{~min}$, and extension at $72{ }^{\circ} \mathrm{C}$ for $2 \mathrm{~min}$, followed by a final extension of $72{ }^{\circ} \mathrm{C}$ for $7 \mathrm{~min}$. 


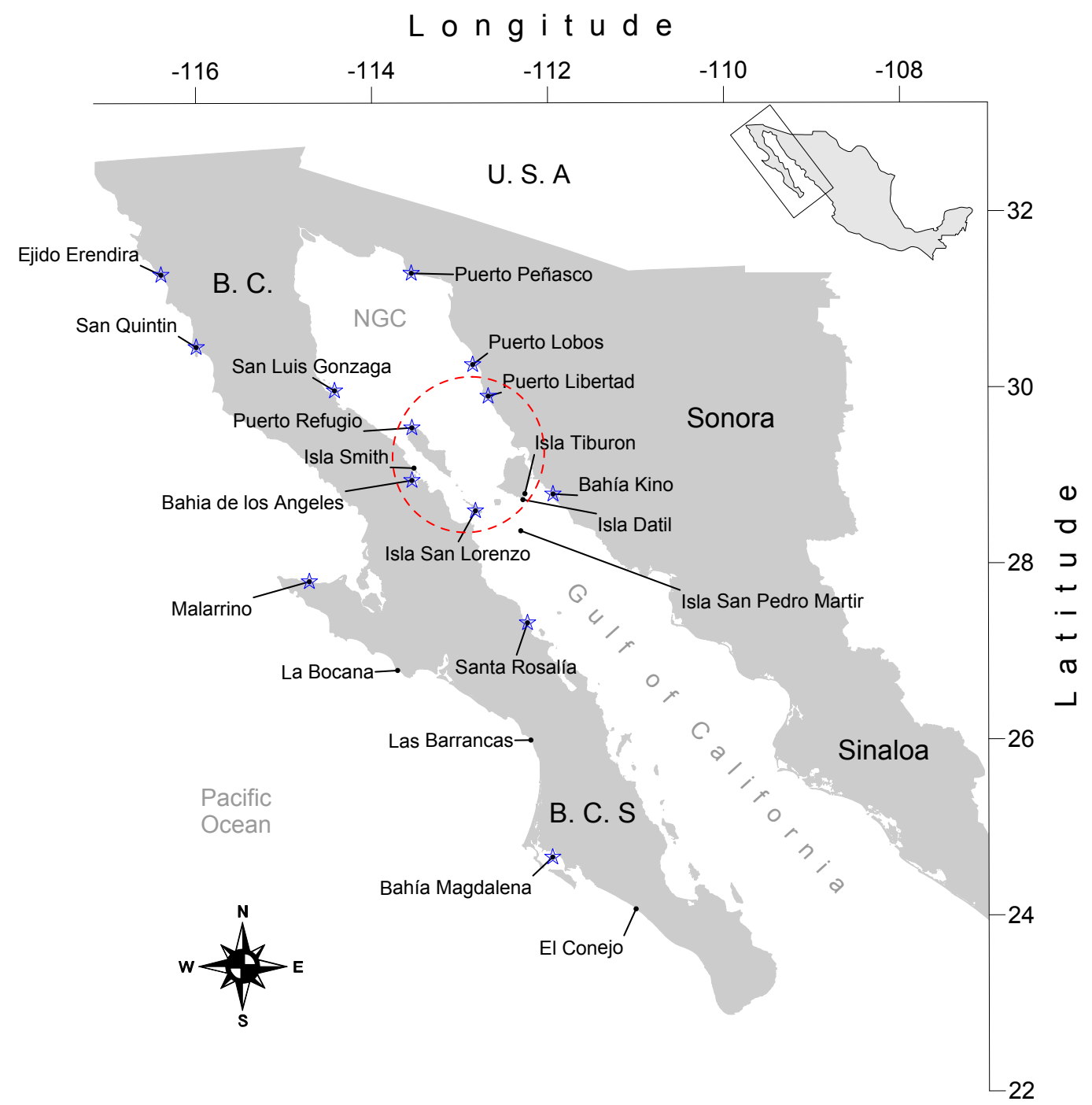

Figure 1 Study area. Locations of 20 octopus populations sampled from Northwest Mexico. B.C, Baja California; B. C. S, Baja California Sur; NGC, Northern Gulf of California. The blue stars represent main fishing localities, and the red circle represents the Midriff Island region.

Full-size DOI: 10.7717/peerj.4295/fig-1

PCR products were purified using ExoSAP (Affimetrix, INC; Santa Clara, CA, USA) and both strands were sequenced on an Applied Biosystems 3730XL DNA Analyzer (Applied Biosystems, Foster City, CA, USA) at the University of Arizona Genetics Core (UAGC).

\section{Genotyping of microsatellites markers}

We tested 15 microsatellite markers developed for O. bimaculatus (Dominguez-Contreras et al., 2014) and based on PCR amplification success selected seven unlinked microsatellites (Ocbi25, Ocbi35, Ocbi39, Ocbi41, Ocbi47, Ocbi48, and Ocbi50) that were polymorphic and informative among the three octopus species. We genotyped 316 samples following PCR methods previously described (Dominguez-Contreras et al., 2014). PCR products were sized on an Applied Biosystems 3730XL DNA Analyzer at the University of Arizona's UAGC 
Core Facility. Microsatellite electropherograms were scored using GeneMarker Version 2.6.0 (SoftGenetics LLC, State College, PA, USA). Allele sizes were assigned into bins using FLEXIBIN (Amos et al., 2007). Deviations from Hardy-Weinberg equilibrium (HWE) were estimated using GENEPOP 4.2 (Raymond \& Rousset, 1995). We used MICROCHECKER 2.2.3 to test for genotyping errors and presence of null alleles (Van Oosterhout et al., 2004).

\section{Species identification}

We used the mitochondrial sequences and microsatellite genotypes to identify species for each sampled individual using phylogenetic analyses of sequence data and Bayesian assignment analyses of microsatellite genotypes. The $16 \mathrm{~S} \mathrm{rDNA}$ and COI sequences were edited using Chromas Pro Version 1.6 and aligned using MUSCLE multiple alignment tools implemented in Mega6 (Tamura et al., 2013). We used JmodelTest 2 (Darriba et al., 2012; Guindon \& Gascuel, 2003) to select the best fit model of nucleotide substitution for phylogenetic analyses using the Akaike and Bayesian information criteria. We applied the Jukes-Cantor (JC) model with 1,000 bootstraps to estimate genetic distances and constructed a Neighbor-joining (NJ) tree using 10,000 bootstraps replications in MEGA (Tamura et al., 2013).

STRUCTURE version 2.3.4 (Pritchard, Stephens \& Donnelly, 2000) was used to analyze microsatellite genotypes using admixture and without prior location information, with allele frequencies correlated among populations. We used a duration of the burnin period of $1 \times 10^{6}$, a number of MCMC repeats after burnin of $2 \times 10^{6}$, with 10 iterations for each number of genetic clusters $(\mathrm{K})$, and $\mathrm{K}$ assumed to vary between 1 and 20. To determine the optimal number of $\mathrm{K}$, we selected the number of clusters by looking at the highest likelihood values (mean of 10 iterations) as well as the highest $\Delta \mathrm{K}$ value implemented in the online software CLUMPAK (Kopelman et al., 2015). We used both values because some evidence has suggested the likelihood method is not always accurate (Evanno, Regnaut \& Goudet, 2005). The value of $\Delta \mathrm{K}$ is based on the rate of change in the log probability of data between successive $\mathrm{K}$ values, which provides a relatively better estimate of the number of genetic clusters (Evanno, Regnaut \& Goudet, 2005). We used the following criteria to assign individuals to species according the their microsatellite genotypes: First, we excluded those samples that showed missing data at two or more loci. Second, we used a majority rule requiring at least $2 / 3(66.66 \%)$ of the probability of assignment to any of the three species, and excluded those individuals where this criterion was not met. Third, we only included individuals where the microsatellite and the mitochondrial data agreed on species assignment.

\section{Genetic diversity and effective population size within species}

The neutral theory of molecular evolution predicts that in a panmictic population of constant size genetic diversity should be proportional to the effective size of the population (Kimura, 1983). This is because in an idealized, panmictic, population the rate of loss of neutral alleles via genetic drift is inversely proportional to the population size (Charlesworth, 2009). Based on recent comparative studies of octopuses, we expect that species with high brood sizes to produce relatively small eggs (O. bimaculatus and O. hubbsorum) and will 
have higher genetic diversity and effective population size than species with comparatively low-fecundity that produce a small number of relatively large eggs (O. bimaculoides) (Table

2) (Ellegren \& Galtier, 2016; Romiguier et al., 2014). We calculated the number of alleles $\left(N_{A}\right)$, effective number of alleles $\left(N_{E}\right.$, which takes into account different sample sizes among localities), expected heterozygosity $\left(H_{E}\right)$ and observed heterozygosity $\left(H_{O}\right)$ with GENALEX 6.501 (Peakall \& Smouse, 2012) to evaluate genetic diversity from the microsatellite data. Allelic richness $\left(R_{A}\right)$ was estimated using HP-Rare to correct for differences in sample size among locations (Kalinowski, 2005).

Private alleles (alleles that are unique to one population) are expected to be more frequent in genetically isolated populations, while their frequency should be considerably lower in well-connected populations (Beger et al., 2014; Munguía-Vega et al., 2015). If we extend this process to populations within each species, then populations of species with limited opportunities for dispersal (direct ontogenetic development, O. bimaculoides) should show higher frequency of private alleles than species with a pelagic paralarval stage (Table 2). Private allelic richness $\left(R_{P A}\right)$ was estimated using HP-Rare to correct for different sample sizes. We estimated a global contemporary effective size $\left(N_{e}\right)$ for each species via the linkage disequilibrium method with a bias correction and a lower allele frequency of 0.05 and 0.02 , and with the molecular coancestry method as implemented in the software NE-ESTIMATOR V2 (Do et al., 2014).

\section{Genetic structure within species}

Species with a long PPD are expected to disperse in a larger area than species with brief or absent PPD (e.g., direct ontogenetic development) (Shanks, 2009). Consequently, $O$. bimaculoides with direct development $(\mathrm{PPD}=0)$ should show higher genetic structure (e.g., global $F_{S T}$ ) (Riginos \& Liggins, 2013), than O. hubbsorum with short PPD and O. bimaculatus with long PPD (Table 2) (Selkoe et al., 2014; Selkoe \& Toonen, 2011). We conducted a hierarchical analysis of molecular of variance (AMOVA) using 999 permutations in GENALEX 6.501 (Peakall \& Smouse, 2012) to estimate the genetic differences observed within and among populations; in other words to estimate genetic structure. We used FreeNA to measure the effect of null alleles on $F_{S T}$ estimates of population structure, taking into account the frequency of null alleles estimated with the expectation maximization method (EM) (Chapuis \& Estoup, 2007).

\section{Genetic relatedness within populations of each species}

The magnitude of local paralarval retention, or the proportion of paralarvae produced within a site that remain in that site, is expected to increase the degree of genetic relatedness (R) within populations (Burgess et al., 2014; Christie et al., 2010). We expect that species with direct ontogenetic development $(\mathrm{PPD}=0$, O. bimaculoides) should have a higher probability for individuals to remain near their hatching site, and thus to show higher levels of genetic relatedness or kinship within populations than the other two species with a planktonic paralarval drift (Table 2). Since local retention is expected to decrease with increasing PPD (Byers \& Pringle, 2006), we expect that genetic relatedness within populations will be lower in the species with the longest known PPD (O. bimaculatus). 
Table 3 Nucleotide divergence of both: 16s rDNA gene and COI gene. Nucleotide divergence between species of octopus identified through the analysis of both the 16s rRNA gene (below the diagonal) and COI gene (above the diagonal). Standard error estimates are shown in parentheses.

\begin{tabular}{llll} 
& O. bimaculoides & O. bimaculatus & O. hubbsorum \\
\hline O. bimaculoides & - & $0.0632( \pm 0.0104)$ & $0.1005( \pm 0.0142)$ \\
O. bimaculatus & $0.0328( \pm 0.0079)$ & - & $0.1042( \pm 0.0139)$ \\
O. hubbsorum & $0.0629( \pm 0.0113)$ & $0.0708( \pm 0.123)$ & - \\
\hline
\end{tabular}

We used Queller \& Goodnight (1989) relatedness metric to calculate pairwise relatedness to describe the number of alleles shared between pairs of individuals and then calculated the average within each population as implemented in GenAlex 6.2 (Peakall \& Smouse, 2012). Statistical significance was assessed by 9,999 permutations and 10,000 bootstraps to estimate $95 \%$ confidence intervals around the hypothesis of random mating.

\section{RESULTS}

\section{Species identification}

A total of 1,054 bp were sequenced for 97 individual samples, including $473 \mathrm{bp}$ from the 16S rRNA gene and 581 bp from the COI gene (GenBank Accession numbers KY985098KY985194 for 16S, and KY985005-KY985097 for COI). The optimum model of substitution according to the Akaike and Bayesian criteria was JC for both 16S rRNA and COI. The resulting NJ of $16 \mathrm{~S}$ rRNA and COI genes showed the monophyletic status of the three species O. bimaculatus, O. bimaculoides and O. hubbsorum (Fig. 2A). O. bimaculoides was present in locations from the west coast of Baja California Peninsula (Ejido Erendira, San Quintin, and Bahía Magdalena), but absent in the Gulf of California. O. bimaculatus was present at only one locality from the west coast of the Baja California Peninsula (Malarrimo) and in samples from the northern Gulf of California including Puerto Peñasco, Puerto Refugio, Puerto Lobos, San Luis Gonzaga, Bahía de los Ángeles and only one individual from Puerto Libertad evidenced with 16S rRNA, (no data was obtained for the COI sequence of this individual). O. hubbsorum was present in several localities from the northern Gulf of California (Puerto Libertad, Isla San Lorenzo, and Bahía Kino) and in the Central Gulf of California (Santa Rosalía) (Fig. 2A). Nucleotide divergence between the three species ranged from $3.3-7.1 \%$ for the $16 \mathrm{~S}$ rRNA gene and from $6.3-10.4 \%$ for the COI gene (Table 3). Octopus bimaculoides showed less divergence with O. bimaculatus (3.3\% and $6.3 \%$, respectively) than with O. hubbsorum (6.3\% and $10.0 \%$, respectively). The largest divergence was observed between O. bimaculatus and O. hubbsorum (7.1\% and 10.4\%, respectively).

We genotyped seven microsatellite loci in 316 individuals collected from 20 localities and observed an average frequency of missing data of 3.75\% (range 1.26-7.27) by locus, and $3.84 \%$ (range 0-28.5) by octopus individual. Hardy-Weinberg tests suggested significant deviations at only 7 out of 140 unique loci/location combinations tested without any clear pattern observed within locations or species (after Bonferroni correction $P=0.00036$ ). Only Ocbi39, Ocbi41 and Ocbi50 significantly deviated in 1, 2 and 4 locations from the 20 locations tested, respectively $(P=0.00036)$. The loci Ocbi41 and Ocbi50 were 


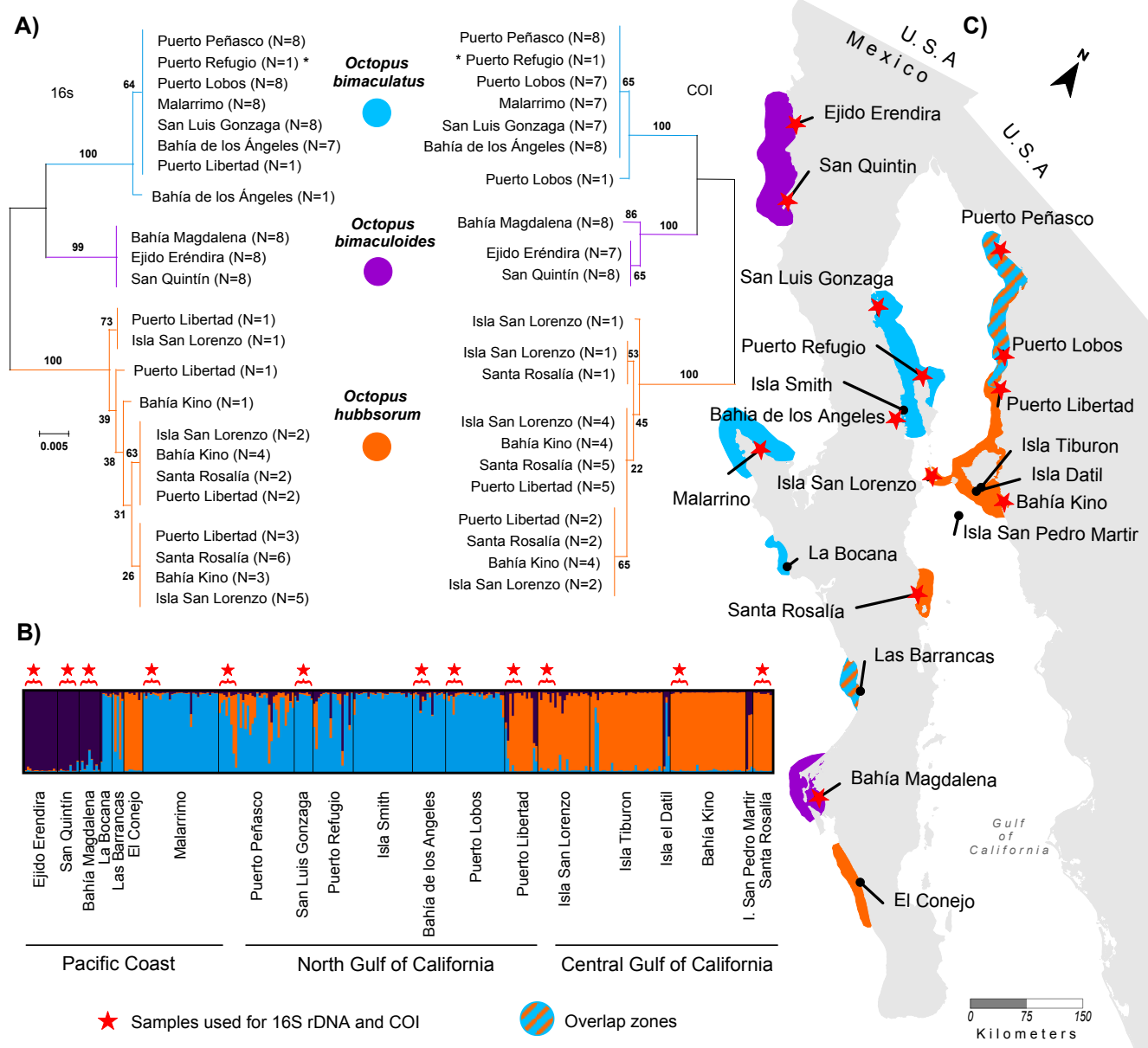

Figure 2 Genetic assignment of octopus samples from fishing localities in Northwest Mexico to three species. Locations used for both 16s rDNA and COI are indicated with stars ( $\hat{\mathrm{e}})$. All locations were used for microsatellites analysis. (A) Neighbor-joining trees constructed with 97 haplotypes for both 16s rDNA and COI for O. bimaculatus (blue), O. bimaculoides (purple) and O. hubbsorum (orange). Bootstrap support $>99 \%$ in 1,000 replicates are shown for branches separating the three species. (B) Bayesian clustering analysis from STRUCTURE showing the probability of individual membership to three genetic clusters ( $K=3,316$ individuals). (C) Distribution of octopus species in 20 localities from Northwest Mexico according to phylogenetic and clustering analyses.

Full-size DOI: 10.7717/peerj.4295/fig-2

monomorphic in 1 and 6 localities, respectively (Table S2). Except for the loci Ocbi35 and Ocbi41, the rest of the loci showed null alleles in at least one locality, with Ocbi39 showing null alleles in eight localities. The EM method showed that average frequency of null alleles among all loci/locations varied from $0.000-0.108$, for O. bimaculatus 0.025 (range 0.000-0.255), for O. bimaculoides 0.026 (range 0.000-0.265), and for O. hubbsorum 0.041 (range 0.000-0.315) (Table S3).

Before assigning individuals to species in order to test our five a-priori hypotheses we excluded individuals that did not meet our criteria. We excluded 17 samples that showed missing data at two or more microsatellite loci. In our dataset, $92.78 \%$ of individuals 
assigned to one species using $16 \mathrm{~S}$ rRNA and COI sequences (Fig. 2A) were correctly assigned to the same species using microsatellite genotypes (Fig. 2B). However, we found 20 individuals that did not comply with the $2 / 3$ rule of ancestry to a single species according to the nuclear genome and were excluded from further analyses. These individuals showed a shared ancestry between O. hubbsorum and O. bimaculatus, mainly in the localities of Puerto Peñasco, Puerto Refugio and Puerto Libertad (Table S4). These locations are within the limit of the geographic range between the two species (Table S5). In Puerto Peñasco, two cases were observed in which the mtDNA identified the individuals as O. bimaculatus, whereas their microsatellite ancestry assigned them to O. hubbsorum (Table S5).

The STRUCTURE analyses showed a modal frequency that supported the presence of at least two clusters or species ( $\Delta K=2$, Fig. S1A) according to the $\Delta K$ method (Evanno, Regnaut \& Goudet, 2005). However, the highest mean value of the ln probability of data for $K=2$ (average $\ln [K]=-8362.29$, Fig. S1B) was close to $K=3$ (average $\ln [K]=-8086.16$, Fig. S1B) in 10/10 repetitions, and in both cases the matrix of similarity scores produced by Clumpak among runs aligned were identical 0.999 (Fig. S1C). The STRUCTURE bar plots (Fig. 2B) showed that $K=3$ clearly distinguished the three clusters or species previously identified in the phylogenetic analyses of the mitochondrial markers and corresponding to O. bimaculoides $(N=36)$, O. bimaculatus $(N=140)$ and $O$. hubbsorum $(N=101)$ among the 20 localities from Northwest Mexico (Fig. 2B). Based on the STRUCTURE analyses, O. bimaculoides is found almost exclusively in the west coast of the Baja California peninsula (Ejido Erendira, San Quintin, and Bahía Magdalena), while the analyses suggested a few individuals inside the Gulf of California were assigned to this species.

Octopus bimaculatus and O. hubbsorum were present in all the area of study. Octopus bimaculatus was collected at La Bocana, Las Barrancas and Malarrimo, and O. hubbsorum in El Conejo along the west coast of Baja California peninsula. In the Gulf of California, O. bimaculatus was collected at Puerto Peñasco, San Luis Gonzaga, Isla Smith, Bahía de Los Angeles and Puerto Lobos. Octopus hubbsorum was present in Puerto Libertad, Isla San Lorenzo, Isla Tiburon, Bahía Kino, and Santa Rosalía (Fig. 2C). STRUCTURE analyses suggested the presence of individuals of $O$. bimaculatus and O. hubbsorum at Las Barrancas in the west coast of Baja California peninsula and Puerto Peñasco, Puerto Refugio and Isla Tiburón in the northern Gulf of California (Figs. 2B and 2C).

\section{Genetic diversity and effective population size within species}

The seven loci were polymorphic for the three species (Table 4). Results generally supported our prediction about higher allelic diversity and effective size in highly fecund species with small eggs (O. bimaculatus and O. hubbsorum) than in species that are less fecund and have larger egg sizes (O. bimaculoides). We observed lower average levels of allelic diversity in O. bimaculoides $\left(N_{E}=3.62 \pm 0.47, R_{A}=4.50 \pm 0.48\right)$ than in O. hubbsorum $\left(N_{E}=5.02 \pm 0.53, R_{A}=4.54 \pm 0.12\right)$, while results for $O$. bimaculatus were mixed and showed the largest diversity of effective alleles $\left(N_{E}=5.64 \pm 0.28\right)$, and the lowest allelic richness $\left(R_{A}=4.14 \pm 0.07\right)$.

We observed that the species with direct ontogenetic development (O. bimaculoides) had the largest average frequency of private alleles $\left(R_{P A}=1.60 \pm 0.48\right)$, compared to the 
Table 4 Genetic variation within populations of three species of octopus. Sample Size $(N)$, Mean \pm Standard Error (SE) of the number of alleles $\left(N_{A}\right)$, effective alleles $\left(N_{E}\right)$, and observed $\left(H_{O}\right)$, expected $\left(H_{E}\right)$ heterozygosities, alellic richness $\left(R_{A}\right)$ and private allelic richness $\left(R_{P A}\right)$.

\begin{tabular}{|c|c|c|c|c|c|c|c|c|}
\hline Species & Population & $N$ & $N_{A}$ & $N_{E}$ & $H_{O}$ & $H_{E}$ & $\boldsymbol{R}_{A}$ & $R_{P A}$ \\
\hline Octopus & Ejido Erendira & 13 & $5.00 \pm 0.93$ & $3.08 \pm 0.52$ & $0.78 \pm 0.08$ & $0.61 \pm 0.07$ & $3.97 \pm 0.64$ & $1.06 \pm 0.27$ \\
\hline \multirow[t]{3}{*}{ bimaculoides } & San Quintín & 9 & $6.14 \pm 1.49$ & $4.44 \pm 1.18$ & $0.52 \pm 0.12$ & $0.62 \pm 0.11$ & $5.46 \pm 1.23$ & $3.28 \pm 1.54$ \\
\hline & Bahía Magdalena & 9 & $4.29 \pm 0.71$ & $3.34 \pm 0.62$ & $0.91 \pm 0.05$ & $0.65 \pm 0.05$ & $4.08 \pm 0.65$ & $2.33 \pm 0.63$ \\
\hline & Mean \pm SE & & $5.00 \pm 0.61$ & $3.62 \pm 0.47$ & $0.74 \pm 0.06$ & $0.63 \pm 0.04$ & $4.50 \pm 0.48$ & $1.60 \pm 0.48$ \\
\hline Octopus & Puerto Libertad & 9 & $5.00 \pm 1.31$ & $4.09 \pm 1.07$ & $0.65 \pm 0.12$ & $0.59 \pm 0.12$ & $4.28 \pm 0.98$ & $0.53 \pm 0.31$ \\
\hline \multirow[t]{6}{*}{ hubbsorum } & Isla San Lorenzo & 19 & $5.71 \pm 1.11$ & $3.87 \pm 0.83$ & $0.62 \pm 0.14$ & $0.61 \pm 0.10$ & $4.43 \pm 0.79$ & $1.59 \pm 0.56$ \\
\hline & Isla Tiburón & 24 & $7.57 \pm 2.07$ & $5.15 \pm 1.53$ & $0.58 \pm 0.15$ & $0.61 \pm 0.13$ & $4.46 \pm 0.96$ & $0.51 \pm 0.24$ \\
\hline & Bahía Kino & 31 & $8.86 \pm 2.22$ & $5.88 \pm 1.50$ & $0.52 \pm 0.12$ & $0.67 \pm 0.10$ & $4.91 \pm 0.91$ & $0.49 \pm 0.18$ \\
\hline & Santa Rosalía & 8 & $9.86 \pm 2.84$ & $6.31 \pm 1.79$ & $0.70 \pm 0.14$ & $0.66 \pm 0.13$ & $4.78 \pm 1.00$ & $0.33 \pm 0.24$ \\
\hline & El Conejo & 8 & $6.57 \pm 1.51$ & $4.82 \pm 1.14$ & $0.75 \pm 0.12$ & $0.66 \pm 0.11$ & $5.00 \pm 0.99$ & $0.69 \pm 0.21$ \\
\hline & Mean $\pm \mathrm{SE}$ & & $7.26 \pm 0.79$ & $5.02 \pm 0.53$ & $0.64 \pm 0.05$ & $0.64 \pm 0.04$ & $4.54 \pm 0.12$ & $0.69 \pm 0.19$ \\
\hline Octopus & La Bocana & 4 & $5.29 \pm 0.47$ & $4.36 \pm 0.54$ & $0.93 \pm 0.07$ & $0.75 \pm 0.03$ & $4.35 \pm 0.34$ & $0.15 \pm 0.04$ \\
\hline \multirow[t]{9}{*}{ bimaculatus } & Las Barrancas & 3 & $3.71 \pm 0.52$ & $3.23 \pm 0.45$ & $0.81 \pm 0.14$ & $0.61 \pm 0.10$ & $3.71 \pm 0.52$ & $0.14 \pm 0.06$ \\
\hline & Malarrimo & 31 & $11.43 \pm 0.81$ & $6.05 \pm 0.82$ & $0.80 \pm 0.08$ & $0.79 \pm 0.06$ & $4.08 \pm 0.30$ & $0.40 \pm 0.15$ \\
\hline & Puerto Peñasco & 21 & $10.29 \pm 1.02$ & $6.67 \pm 1.04$ & $0.87 \pm 0.07$ & $0.79 \pm 0.07$ & $4.21 \pm 0.36$ & $0.33 \pm 0.08$ \\
\hline & San Luis Gonzaga & 8 & $6.71 \pm 1.02$ & $5.20 \pm 0.76$ & $0.79 \pm 0.14$ & $0.71 \pm 0.12$ & $4.02 \pm 0.51$ & $0.12 \pm 0.06$ \\
\hline & Puerto Refugio & 12 & $8.00 \pm 1.02$ & $5.65 \pm 0.81$ & $0.68 \pm 0.11$ & $0.76 \pm 0.08$ & $4.07 \pm 0.38$ & $0.33 \pm 0.11$ \\
\hline & Isla Smith & 25 & $11.14 \pm 1.24$ & $6.76 \pm 0.89$ & $0.84 \pm 0.06$ & $0.81 \pm 0.06$ & $4.25 \pm 0.32$ & $0.40 \pm 0.09$ \\
\hline & B.de Los Ángeles & 14 & $9.57 \pm 0.75$ & $6.20 \pm 0.89$ & $0.68 \pm 0.10$ & $0.78 \pm 0.07$ & $4.23 \pm 0.35$ & $0.24 \pm 0.04$ \\
\hline & Puerto Lobos & 20 & $10.14 \pm 0.86$ & $6.64 \pm 0.79$ & $0.80 \pm 0.08$ & $0.82 \pm 0.04$ & $4.34 \pm 0.23$ & $0.44 \pm 0.17$ \\
\hline & Mean $\pm \mathrm{SE}$ & & $8.48 \pm 0.43$ & $5.64 \pm 0.29$ & $0.80 \pm \mathbf{0 . 0 3}$ & $0.76 \pm 0.02$ & $4.14 \pm 0.07$ & $0.28 \pm 0.04$ \\
\hline
\end{tabular}

Table 5 Contemporary effective population size. Average and $95 \%$ confidence intervals for the contemporary effective population size $\left(N_{e}\right)$ for three species of octopus. Locations were pooled according to the results of the genetic assignment of species (Fig. 2). $N_{e}$ was estimated with two methods, including linkage disequilibrium (LD; lowest allele frequency used 0.05 and 0.02 respectively) and Molecular coancestry $\left(M_{C}\right)$.

\begin{tabular}{llll} 
& LDNE $\mathbf{0 . 0 5}$ & LDNE 0.02 & $\boldsymbol{M}_{\boldsymbol{C}}$ \\
\hline O. bimaculoides & $9.7(6.4-13.9)$ & $17.9(13.6-24.0)$ & $9.9(3.6-19.2)$ \\
O. bimaculatus & $190.2(129.2-324.2)$ & $252.7(182.8-388.8)$ & $\infty(\infty-\infty)$ \\
O. hubbsorum & $104.8(69.9-181.3)$ & $131.4(95.7-197.1)$ & $28.1(6.8-64.3)$ \\
\hline
\end{tabular}

species with a planktonic paralarval phase (Table 4). The lowest values were observed in O. bimaculatus $\left(R_{P A}=0.28 \pm 0.04\right)$, while $O$. hubbsorum showed intermediate values $\left(R_{P A}=0.69 \pm 0.19\right)$.

We observed the largest contemporary effective population size $N_{e}$ in O. bimaculatus using both the linkage disequilibrium and the molecular coancestry methods (average $\left.\mathrm{LDNE}=190-252, M_{C}=\infty\right)$, followed by O. hubbsorum $\left(\mathrm{LDNE}=104-131, M_{C}=28.1\right.$. O. bimaculoides had the lowest effective size according to the two methods (LDNE $=10-18$, $\left.M_{C}=10\right)$ (Table 5). 


\begin{tabular}{|c|c|c|c|c|c|c|c|}
\hline Species & Source of variation & Variance & $d f$ & Sum of squares & Means of squares & Estimated variance & $P$ value \\
\hline Octopus & Among Populations $\left(F_{S T}\right)$ & $19 \%$ & 2 & 28.808 & 14.404 & 0.610 & 0.000 \\
\hline \multirow{3}{*}{ extbfbimaculoides } & Among Indiv $\left(F_{I S}\right)$ & $0 \%$ & 28 & 56.338 & 2.012 & 0.000 & 1.000 \\
\hline & Within Indiv $\left(F_{I T}\right)$ & $81 \%$ & 31 & 80.000 & 2.581 & 2.581 & 0.005 \\
\hline & Total & $100 \%$ & 61 & 165.145 & & 3.190 & \\
\hline Octopus & Among Populations $\left(F_{S T}\right)$ & $16 \%$ & 5 & 87.004 & 17.401 & 0.471 & 0.000 \\
\hline \multirow[t]{3}{*}{ hubbsorum } & Among Indiv $\left(F_{I S}\right)$ & $11 \%$ & 93 & 256.834 & 2.762 & 0.308 & 0.000 \\
\hline & Within Indiv $\left(F_{I T}\right)$ & $73 \%$ & 99 & 212.500 & 2.146 & 2.146 & 0.000 \\
\hline & Total & $100 \%$ & 197 & 556.338 & & 2.925 & \\
\hline Octopus & Among Populations $\left(F_{S T}\right)$ & $9 \%$ & 8 & 92.321 & 11.540 & 0.293 & 0.000 \\
\hline \multirow[t]{3}{*}{ bimaculatus } & Among Indiv $\left(F_{I S}\right)$ & $3 \%$ & 129 & 380.349 & 2.948 & 0.094 & 0.003 \\
\hline & Within Indiv $\left(F_{I T}\right)$ & $88 \%$ & 138 & 381.000 & 2.761 & 2.761 & 0.000 \\
\hline & Total & $100 \%$ & 275 & 853.670 & & 3.148 & \\
\hline
\end{tabular}

\section{Genetic structure within species}

Pooling sampling locations according to species molecular identification (Fig. 1), we found that the microsatellite data AMOVA test supported the prediction that O. bimaculoides with direct ontogenetic development had higher levels of genetic structure $\left(F_{S T}=0.19\right.$, $P=0.000$ ), compared to species with pelagic paralarvae (Table 6). Also, we accepted the hypothesis that $O$. bimaculatus, with the longest PPD, had overall lower genetic structure $\left(F_{S T}=0.09, P=0.000\right)$ compared with $O$. hubbsorum, with relatively shorter $\operatorname{PPD}\left(F_{S T}=0.16, P=0.000\right)$.

The frequency of null alleles can affect the estimates of genetic differentiation, decreasing the genetic diversity and overestimating the $F_{S T}$ values (Chapuis \& Estoup, 2007). Genetic differentiation with $\left(\right.$ Null $\left.F_{S T}\right)$ and without $\left(F_{S T}\right)$ null alleles estimated with FreeNA were similar within each species: $O$. bimaculoides (Null $F_{S T}=0.214$ and $F_{S T}=0.221$ ), O. bimaculatus (Null $F_{S T}=0.092$ and $\left.F_{S T}=0.088\right)$ and $O$. hubbsorum (Null $F_{S T}=0.102$ and $\left.F_{S T}=0.110\right)$ (Table S6).

\section{Genetic relatedness within populations of each species}

The average genetic relatedness for three octopus species were significantly greater than expectations based on random mating (all values $p=0.000$, Fig. 3 ). We found that O. bimaculoides with direct ontogenetic development (no paralarval planktonic stage) had the highest average relatedness within populations $(R=0.209)$, followed by O. hubbsorum with intermediate PPD $(R=0.135)$, while O. bimaculatus with the longest PPD had the lowest mean level of relatedness $(R=0.020)$.

\section{DISCUSSION}

We analyzed slowly evolving haploid markers (the mitochondrial genes 16S rRNA and COI) and rapidly-evolving, hypervariable, nuclear markers (seven microsatellite loci) to infer the geographic distribution of three molecularly identified species of octopus among 20 fishing localities from Northwest Mexico and corroborated that differences in 


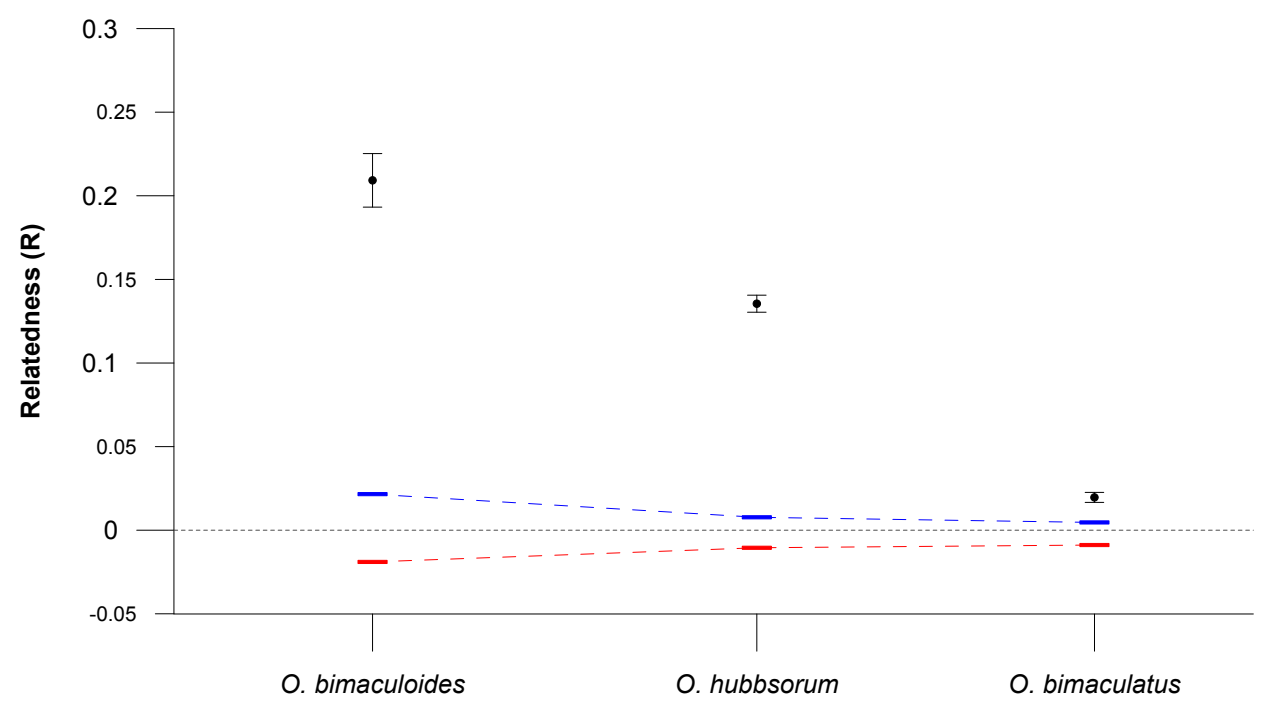

Figure 3 Relatedness within three octopus species. Mean pairwise relatedness $(R)$ values ( $\pm 95 \%$ confidence intervals) within three octopus species, compared with bootstrapped upper (blue) and lower (red) $95 \%$ confidence intervals assuming random mating (10,000 bootstraps replicates).

Full-size DOI: 10.7717/peerj.4295/fig-3

the fecundity and potential paralarval planktonic drift (or lack thereof) influence genetic diversity and population structure found within each species.

A minimum of $3 \%$ genetic divergence in the COI gene is considered a threshold to distinguish species in metazoans (Hebert et al., 2003). We found a higher divergence among the three species $(6 \%-10 \%)$, suggesting they are reproductively isolated biological taxa. We observed a smaller nucleotide divergence between O. bimaculoides and O. bimaculatus probably due to their more recent divergence from a common ancestor (Hebert et al., 2003). The three octopus species studied here are the main targets for small-scale fisheries in Northwest Mexico and our results showed that, although their distribution ranges sometimes overlap, most of the 20 surveyed localities had evidence for the presence of a single species fishery, which occur in different habitats. O. bimaculoides distribute in coastal habitats with low wave energy (enclosed bays and coastal lagoons), although this species also lives at $20 \mathrm{~m}$ depth in rocky and forests kelp habitats (Forsythe \& Hanlon, 1988a; Sinn, 2008). Along the west coast of the Baja California peninsula exist at least 16 coastal lagoons located between Ensenada (Baja California) and Bahía Magdalena (Baja California Sur) (Lankford, 1977), which probably have been colonized by stepping-stone events among distinct lagoons during rafting behavior (Gillespie et al., 2012). Rafting has been documented for O. bimaculoides and O. bimaculatus on floating objects like macroalgae (Thiel \& Gutow, 2005). This paralarval dispersal mechanism could explain progressive colonization events that increase the range distribution into favorable habitats. Our study expanded the previously known range distribution of the three species along the west coast of Baja California peninsula $\sim 800 \mathrm{~km}$ southward for O. bimaculoides, $\sim 400 \mathrm{~km}$ southward for O. bimaculatus and $\sim 150 \mathrm{~km}$ northward for O. hubbsorum. O. bimaculatus was restricted to the northern region of the Gulf of California where its distribution 
might be influenced by the geographic extent of a cyclonic (anti-clockwise) oceanographic gyre that drift paralarvae during its summer spawning period (Castellanos-Martinez, 2008; Marinone et al., 2008; Munguia-Vega et al., 2014). O. bimaculatus seems to show the pattern of disjunct distribution reported for several temperate species of invertebrates and fishes that are present in the northern part of the west coast of the Baja California peninsula, disappear in the southern region of the Gulf of California and reappear in the northern region of the Gulf of California (Bernadi, Findley \& Rocha-Olivares, 2003). The distribution range of $O$. hubbsorum was conceptually redefined here to include the south part of the Midriff Island region in the Gulf of California (López-Uriarte, Ríos-Jara \& Pérez-Peña, 2005; Moreno-Báez et al., 2012). Given the low number of individuals assigned to O. bimaculoides in the Gulf of California, we recommend that further surveys for the species be conducted before the range of the species can be confidently expanded into the Gulf of California.

The three species were sympatric along the west coast of the Baja California peninsula around the Bahia Magdalena region, while in the Gulf of California only O. bimaculatus and O. hubbsorum were sympatric around the Midriff Island region. Both regions have been considered transition zones between temperate and tropical species (Briggs, 1974; Briggs $\&$ Bowen, 2012; Brusca, 2010). Given our samples were collected mainly during warm season, it is important to consider the possibility that O. bimaculatus and O. hubbsorum could be sharing the same shelters around the Midriff Islands region in different season of the year, with $O$. bimaculatus being more frequent during the cold-temperate period (October-March), while O. hubbsorum prefers warm-tropical water conditions (AprilSeptember). A pattern of alternate presence of the two species with different thermal preferences could explain why the octopus fishery is carried out through the year in the northern Gulf of California (Moreno-Báez et al., 2012). Thus, at several localities in the northern Gulf of California both species could be the main target of the fishery during different seasons, and at least in some localities where samples in our study were assigned to O. bimaculatus (e.g., Puerto Lobos) there have been recent field (October 2016) observations were only O. hubbsorum individuals were recorded (JF Domínguez-Contreras and A Munguía-Vega, pers. comm., 2016), highlighting the need for seasonal data to complement our current understanding of species captured, particularly in localities near the biogeographic transition zones. Individuals with mixed ancestry that could not been assigned to a single species based on our criteria were found at locations were both O. hubbsorum and O. bimaculatus seem to be present in the northern Gulf of California. These mixed individuals could be the result of either low statistical power of the seven loci employed or hybrids between the two species. Hybridization between octopuses has not yet been documented, however, the copulatory behavior between different octopus species has been recorded, possibly due to low mate availability and a short lifespan (Lutz \& Voight, 1994). The likely hybridization in Northwest Mexico should be further studied with a larger sample of nuclear markers.

The life history strategies of each of the three octopus species strongly influenced the genetic diversity and structure among species, showing significant differences in population dynamics and paralarval connectivity. O. bimaculoides without a planktonic 
phase (direct ontogenetic development) had the smallest effective population size and the lowest genetic diversity (effective alleles) and showed higher levels of relatedness within populations, more structure among populations and a higher proportion of private alleles, compared to the two octopus species with a planktonic paralarval stage. These observations suggest that populations of $O$. bimaculoide s are comparatively smaller and structured at a local geographic scale, and are likely highly denso-dependent upon local recruitment. In contrast, O. hubbsorum and O. bimaculatus have comparatively higher fecundity and with planktonic paralarval drift that increase their dispersal potential and opportunities for gene flow among populations (Villanueva et al., 2016). These results are consistent with our hypotheses about a larger effective population size that is associated to higher levels of effective alleles and lower levels of genetic relatedness within populations, less genetic structure among populations and lower frequency of private alleles. This implies that O. hubbsorum and O. bimaculatus might depend less on local paralarval retention and more on paralarval dispersal among different populations. However, O. bimaculatus had lower levels of genetic differentiation among populations, lower frequency of private alleles that translated into an overall lower allelic richness and lower genetic relatedness within populations compared to O. hubbsorum. In addition, effective alleles and effective population size in O. hubbsorum were lower compared to O. bimaculatus. Although no studies exist about the PPD of $O$. hubbsorum, our results are consistent with a relatively shorter PPD and less potential for dispersal compared to O. bimaculatus. This agrees with a recent study suggesting that for species with a planktonic phase, the duration of the planktonic phase increases with mantle length at hatchling (O. hubbsorum $=1.2$ mm ML O. bimaculatus $=2.6$ mm ML (Alejo-Plata \& Herrero-Alejo, 2014; Ambrose, 1981; Villanueva et al., 2016).

An inability to easily identify biological species hampers any effort towards their management and conservation (Bickford et al., 2007). The distinct biogeography and habitat distributions along with contrasting life history traits are expected to have strong direct effects on population parameters. These are key biological features for establishing the spatial scale, location and timing of management actions and rates of sustainable fishing for each species. Therefore, is not advisable to continue with the current management that does not differentiate among the three species. O. bimaculoides with a lower effective population size, and with local populations that are mostly self-sustaining and partially isolated from other nearby populations could be highly susceptible to over exploitation, severe bottlenecks and could show long recovery times if fisheries management erroneously considers all populations as a single stock and ignores the biological and ecological relevance of local population dynamics. O. bimaculoides management taking place at the level of local populations has advantages over single stock management, for instance, it would be possible to assign rigorous catch quotes per individual bay. The species with higher fecundity and dispersal potential (O. bimaculatus and O. hubbsorum) may benefit from implementation of management tools that consider metapopulation dynamics on a larger geographic scale and the presence of larval dispersal among populations, identifying key paralarval sources and paralarval dispersal routes during the PPD, spawning and hatching seasons for each species. 
A critical consideration for management of the octopus fishery in the northern Gulf of California is the difference in the spawning seasons between O. hubbsorum (spring and fall) and O. bimaculatus (summer) and its relationship to the current patterns (direction and speed) of paralarval dispersal and its impact on source-sink metapopulation dynamics. Ocean current patterns in the northern Gulf of California are highly directional, or asymmetric, driven by a cyclonic (anti-clockwise) gyre during spring and summer (Marinone, 2012; Marinone et al., 2008) when both O. hubbsorum and O. bimaculatus spawn. However, O. hubbsorum also spawns during autumn and winter (JF DomínguezContreras and A Munguía-Vega, pers. comm., 2016) when the northern Gulf of California gyre reverses to an anti-cyclonic (clockwise) direction (Lavin \& Marinone, 2003; Marinone, 2012), effectively transforming key larval sources during spring-summer into larval sinks during autumn-winter. When implementing spatial management tools in systems with strong asymmetry in the direction of the currents, including marine reserves, it is advised that reserves are located upstream according to the main flow to protect the sources of larvae that support multiple downstream fishing sites (Beger et al., 2014; Munguia-Vega et al.,

2014). These observations imply that selection of the location of marine reserves for octopus in the northern Gulf of California must consider the cyclonic phase of the oceanographic gyre for both octopus species and the influence of the currents during the anti-cyclonic phase for O. hubbsorum. Also, temporal fishing closures based on the spawning period of a single species, like the one recently implemented in the northern Gulf of California based on O. bimaculatus (Opinión Técnica No. RJL/INAPESCA/DGAIPP/1065/2015; DOF, 2016, 01 junio), might be only partially effective for protecting the recruitment of the other species present in the same locations but with a different spawning season (O. hubbsorum, LópezUriarte, Ríos-Jara es Pérez-Peña, 2005; Moreno-Báez et al., 2012). Similarly, minimum sizes of capture established based on size at sexual maturity for O. bimaculatus might overestimate the minimum size required for $O$. hubbsorum (Table 1). Also beneficial is recognizing that growth and reproductive biology in octopus is augmented by higher temperatures and food availability (Forsythe \& Hanlon, 1988b). Our findings highlight that sustainable fisheries management will heavily depend upon establishing management tools that match the geographic and habitat distribution, life history and population dynamics of the biological species targeted by multi-specific fisheries.

\section{ACKNOWLEDGEMENTS}

We thank several fishing cooperatives, civil society organizations and fisherman that helped collecting octopus samples: Sociedades Cooperativas de Producción Pesquera: de La Purísima, de Bahía Magdalena y de Puerto Chale, fisherman from San Quintin and Ejido Erendira, Dra. Ivonne Posada, and partners of the PANGAS project including Centro Intercultural de Estudio de Desiertos y Oceános A.C. (CEDO), Comunidad y Biodiversidad A.C, Pronatura Noroeste A.C. and fishing cooperatives from the Northern Gulf of California. Karla Vargas and Stacy L. Sotak helped us at various stages during microsatellite genotyping at the University of Arizona. Jaime Gómez-Gutíerrez provided valuable feedback on earlier versions of the manuscript. 


\section{ADDITIONAL INFORMATION AND DECLARATIONS}

\section{Funding}

This research was partially financed by Secretaria de Investigación y Posgrado projects: 20120971, 20121594, 20130059, 20130089, 20140781, 20140465, 20150998, 20150117, CONACyT 108230 and institutional fund CONACyT Fronteras de la Ciencia 292/2016. José F Domínguez-Contreras benefited from Consejo Nacional de Ciencia y Tecnología doctoral (328943) and postdoctoral (291053 estancias posdoctorales nacionales 2016-1) scholarships. This work was partially supported via the PANGAS Science Coordination by the David and Lucile Packard Foundation grants \#2013-39400, \#2015-62798. There was no additional external funding received for this study. The funders had no role in study design, data collection and analysis, decision to publish, or preparation of the manuscript.

\section{Grant Disclosures}

The following grant information was disclosed by the authors:

Secretaria de Investigación y Posgrado: 20120971, 20121594, 20130059, 20130089,

20140781, 20140465, 20150998, 20150117.

CONACYT: 108230.

CONACyT Fronteras de la Ciencia: 292/2016.

Consejo Nacional de Ciencia y Tecnología doctoral: 328943.

postdoctoral: 291053.

David and Lucile Packard Foundation: \#2013-39400, \#2015-62798.

\section{Competing Interests}

The authors declare there are no competing interests. Any use of trade, firm, or product names is for descriptive purposes only and does not imply endorsement by the US Government.

\section{Author Contributions}

- José F. Domínguez-Contreras and Adrian Munguia-Vega conceived and designed the experiments, performed the experiments, analyzed the data, contributed reagents/materials/analysis tools, wrote the paper, prepared figures and/or tables, reviewed drafts of the paper.

- Bertha P. Ceballos-Vázquez, Marcial Arellano-Martínez, Francisco J. García-Rodríguez, Melanie Culver and Hector Reyes-Bonilla contributed reagents/materials/analysis tools, prepared figures and/or tables, reviewed drafts of the paper.

\section{Field Study Permissions}

The following information was supplied relating to field study approvals (i.e., approving body and any reference numbers):

Field experiments were approved by Secretaría de Agricultura, Ganadería, Desarrollo Rural, Pesca y Alimentación (SAGARPA). 


\section{DNA Deposition}

The following information was supplied regarding the deposition of DNA sequences:

The COI and 16S rDNA sequences described here are accessible via GenBank accession numbers KY985098 to KY985194.

\section{Data Availability}

The following information was supplied regarding data availability:

The raw data is provided in the Supplemental Files.

\section{Supplemental Information}

Supplemental information for this article can be found online at http://dx.doi.org/10.7717/ peerj.4295\#supplemental-information.

\section{REFERENCES}

Alejo-Plata M, Gómez-Márquez JL. 2015. Reproductive biology of Octopus hubbsorum (Cephalopoda: Octopodidae) from the coast of Oaxaca, Mexico. American Malacological Bulletin 33:89-100 DOI 10.4003/006.033.0117.

Alejo-Plata M, Gómez-Márquez JL, Ramos-Carrillo S, Herrera-Galindo JE. 2009. Reproducción, dieta y pesquería del pulpo Octopus hubbsorum (Mollusca: Cephalopoda) en la costa de Oaxaca, México. Revista de Biología Tropical 57:63-79.

Alejo-Plata M, Herrero-Alejo S. 2014. First description of eggs and paralarvae of green octopus Octopus hubbsorum (cephalopoda: Octopodidae) under laboratory conditions. American Malacological Bulletin 32:132-139 DOI 10.4003/006.032.0101.

Ambrose RF. 1981. Observations on the embryonic development and early post embryonic behavior of Octopus bimaculatus (MOLLUSCA: CEPHALOPODA). Veliger 24:139-147.

Ambrose RF. 1990. Octopus bimaculatus. In: Land MA, Hochberg FG, eds. Proceedings of the workshop on the fishery and market potential of octopus in California. Washinton, D.C.: Smithsonian Institution, 11-22.

Amos W, Hoffman JI, Frodsham A, Zhang L, Best S, Hill AVS. 2007. Automated binning of microsatellite alleles: problems and solutions. Molecular Ecology Notes 7:10-14 DOI 10.1111/j.1471-8286.2006.01560.x.

Arkhipkin AI, Rodhouse PGK, Pierce GJ, Sauer W, Sakai M, Allcock L, Arguelles J, Bower JR, Castillo G, Ceriola L, Chen C-S, Chen X, Diaz-Santana M, Downey N, González AF, Granados Amores J, Green CP, Guerra A, Hendrickson LC, Ibáñez C, Ito K, Jereb P, Kato Y, Katugin ON, Kawano M, Kidokoro H, Kulik VV, Laptikhovsky VV, Lipinski MR, Liu B, Mariátegui L, Marin W, Medina A, Miki K, Miyahara K, Moltschaniwskyj N, Moustahfid H, Nabhitabhata J, Nanjo N, Nigmatullin CM, Ohtani T, Pecl G, Perez JAA, Piatkowski U, Saikliang P, Salinas-Zavala CA, Steer M, Tian Y, Ueta Y, Vijai D, Wakabayashi T, Yamaguchi T, Yamashiro C, Yamashita N, Zeidberg LD. 2015. World squid fisheries. Reviews in Fisheries Science \& Aquaculture 23:92-252 DOI 10.1080/23308249.2015.1026226. 
Beger M, Selkoe KA, Treml EA, Barber PH, Von der Heyden S, Crandall ED, Toonen RJ, Riginos C. 2014. Evolving coral reef conservation with genetic information. Bulletin of Marine Science 90:159-185 DOI 10.5343/bms.2012.1106.

Bernadi G, Findley L, Rocha-Olivares A. 2003. Vicariance and dispersal across Baja California in disjunct marine fish populations. Evolution 7:1599-1609.

Berry SS. 1953. Preliminary diagnoses of six west american species of octopus. Leaflets in Malacology 1:51-58.

Bickford D, Lohman DJ, Sodhi NS, Ng PK, Meier R, Winker K, Ingram KK, Das I. 2007. Cryptic species as a window on diversity and conservation. Trends in Ecology \& Evolution 22:148-155 DOI 10.1016/j.tree.2006.11.004.

Boyle PR, Von Boletzky S. 1996. Cephalopod populations: definition and dynamics. Philosophical Transactions of the Royal Society of London Series B: Biological Sciences 351:985-1002 DOI 10.1098/rstb.1996.0089.

Briggs JC. 1974. Marine zoogeography. New York: McGraw-Hill, Inc.

Briggs JC, Bowen BW. 2012. A realignment of marine biogeographic provinces with particular reference to fish distributions. Journal of Biogeography 39:12-30

DOI 10.1111/j.1365-2699.2011.02613.x.

Brusca RC. 1980. Common intertidal invertebrates of the Gulf of California. Tucson, Arizona: The University of Arizona Press.

Brusca RC. 2010. The Gulf of California: biodiversity and conservation. Tuscon: University of Arizona Press.

Burgess SC, Nickols KJ, Griesemer CD, Barnett LAK, Dedrick AG, Satterthwaite EV, Yamane L, Morgan SG, White JW, Botsford LW. 2014. Beyond connectivity: how empirical methods can quantify population persistence to improve marine protected area design. Ecological Applications 24:257-270 DOI 10.1890/13-0710.1.

Byers JE, Pringle JM. 2006. Going against the flow: retention, range limits and invasions in advective environments. Marine Ecology Progress Series 313:27-41 DOI 10.3354/meps313027.

Cardenas-Robles ED. 2013. Fecundidad en el pulpo Octopus bimaculatus Verrill, 1883 (CEPHALOPODA:OCTOPODIDADE)en Bahía de Los Ángeles, Baja California, México. Bachelor, Universidad Autonoma de Baja California Sur.

Castellanos-Martínez S. 2008. Reproducción del pulpo Octopus bimaculatus Verrill, 1883 en Bahía de los Ángeles, Baja California. Master thesis, Instituto politécnico Nacional, México.

Chapuis MP, Estoup A. 2007. Microsatellite null alleles and estimation of population differentiation. Molecular Biology and Evolution 24:621-631 DOI 10.1093/molbev/msl191.

Charlesworth B. 2009. Effective population size and patterns of molecular evolution and variation. Nature Review Genetics 10:195-205 DOI 10.1038/nrg2526.

Christie MR, Johnson DW, Stallings CD, Hixon MA. 2010. Self-recruitment and sweepstakes reproduction amid extensive gene flow in a coral-reef fish. Molecular Ecology 19:1042-1057 DOI 10.1111/j.1365-294X.2010.04524.x. 
CONAPESCA. 2014. Anuario estadístico de acuacultura y pesca 2013. Mazatlán: Comisión Nacional de Acuacultura y Pesca.

Darriba D, Taboada GL, Doallo R, Posada D. 2012. jModelTest 2: more models, new heuristics and parallel computing. Nature Methods 9:772 DOI 10.1038/nmeth.2109.

Do C, Waples RS, Peel D, Macbeth GM, Tillett BJ, Ovenden JR. 2014. NeEstimator v2: re-implementation of software for the estimation of contemporary effective population size (Ne) from genetic data. Molecular Ecology Resources 14:209-214 DOI 10.1111/1755-0998.12157.

Diario Oficial de la Federación (DOF). 2016. Acuerdo por el que se establece la veda temporal y tallas mínimas de captura para la pesca de las especies de pulpo en Bahía de los Ángeles. Baja California, publicado el 1 de junio de 2016. Available at http://www.dof.gob.mx/nota_detalle.php?codigo=5503748\&fecha=07/11/2017.

Domínguez-Contreras JF. 2011. Reproducción del pulpo Octopus hubbsorum Berry, 1953 en Bahía Magdalena. BCS, México. Master, Mexico City, UNAM.

Domínguez-Contreras JF, Ceballos-Vázquez BP, Hochberg FG, Arellano-Martínez M. 2013. A new record in a well-established population of Octopus hubbsorum (Cephalopoda: Octopodidae) expands its known geographic distribution range and maximum size. American Malacological Bulletin 31:95-99 DOI 10.4003/006.031.0122.

Domínguez-Contreras JF, Munguía-Vega A, Ceballos-Vázquez BP, Arellano-Martínez M, Culver M. 2014. Characterization of microsatellite loci from two-spotted octopus Octopus bimaculatus Verrill 1883 from pyrosequencing reads. Conservation Genetics Resources 6:465-468 DOI 10.1007/s12686-013-0128-x.

Doubleday ZA, Prowse TAA, Arkhipkin A, Pierce GJ, Semmens J, Steer M, Leporati SC, Lourenço S, Quetglas A, Sauer W, Gillanders BM. 2016. Global proliferation of cephalopods. Current Biology 26:R406-R407 DOI 10.1016/j.cub.2016.04.002.

Ellegren H, Galtier N. 2016. Determinants of genetic diversity. Nature Review Genetics 17:422-433 DOI 10.1038/nrg.2016.58.

Evanno G, Regnaut S, Goudet J. 2005. Detecting the number of clusters of individuals using the software STRUCTURE: a simulation study. Molecular Ecology 14:2611-2620 DOI 10.1111/j.1365-294X.2005.02553.x.

FAO. 2015. The state of world fisheries and aquaculture, Food and Agriculture. Rome: Organization of the United Nations.

Finkbeiner EM. 2015. The role of diversification in dynamic small-scale fisheries: lessons from Baja California Sur, Mexico. Global Environmental Change 32:139-152 DOI 10.1016/j.gloenvcha.2015.03.009.

Finkbeiner EM, Basurto X. 2015. Re-defining co-management to facilitate small-scale fisheries reform: an illustration from northwest Mexico. Marine Policy 51:433-441 DOI 10.1016/j.marpol.2014.10.010.

Folmer O, Black M, Hoeh W, Lutz R, Vrijenhoek R. 1994. DNA primers for amplification of mitochondrial cytochrome c oxidase subunit I from diverse metazoan invertebrates. Molecular Marine Biology and Biotechnology 3:294-299. 
Forsythe JW, Hanlon RT. 1988a. Behavior, body patterning and reproductive biology of Octopus bimaculoides from California. Malacologia 29:41-55.

Forsythe JW, Hanlon RT. 1988b. Effect of temperature on laboratory growth, reproduction and life-span of Octopus bimaculoides. Marine Biology 98:369-379 DOI 10.1007/Bf00391113.

Garcia-Vazquez E, Machado-Schiaffino G, Campo D, Juanes F. 2012. Species misidentification in mixed hake fisheries may lead to overexploitation and population bottlenecks. Fisheries Research 114:52-55 DOI 10.1016/j.fishres.2011.05.012.

Gillespie RG, Baldwin BG, Waters JM, Fraser CI, Nikula R, Roderick GK. 2012. Longdistance dispersal: a framework for hypothesis testing. Trends in Ecology \& Evolution 27:47-56 DOI 10.1016/j.tree.2011.08.009.

González-Meléndez M. 2012. Análisis cualitativo sobre el método de pesca para el pulpo de laguna Guerrero Negro, B C S, y sus implicaciones sociales Bachelor. Mexicali, UABCS.

Gotshall DW. 1998. Marine animals of Baja California: a guide to the common fishes and invertebrates Baja California to Panama. California: Monterey.

Guindon S, Gascuel O. 2003. A simple, fast, and accurate algorithm to estimate large phylogenies by maximum likelihood. Systematic Biology 52:696-704 DOI 10.1080/10635150390235520.

Hanlon RT. 1988. Behavioral and body patterning characters useful in taxonomy and field identification of cephalopods. Malacologia 29:247-264.

Hebert PD, Cywinska A, Ball SL, De Waard JR. 2003. Biological identifications through DNA barcodes. Proceedings of the Royal Society B: Biological Sciences 270:313-321 DOI 10.1098/rspb.2002.2218.

Hochberg FG, Fields WG. 1980. Cephalopoda: the squids and octopuses. In: Morris $\mathrm{MH}$, Abbott DP, Haderlie EC, eds. Intertidal invertebrates of California. Stanford: Stanford University Press, 429-444.

Hunsicker ME, Essington TE, Watson R, Sumaila UR. 2010. The contribution of cephalopods to global marine fisheries: can we have our squid and eat them too? Fish and Fisheries 11:421-438 DOI 10.1111/j.1467-2979.2010.00369.x.

Iglesias J, Sánchez FJ, Bersano JGF, Carrasco JF, Dhont J, Fuentes L, Linares F, Muñoz JL, Okumura S, Roo J, Van der Meeren T, Vidal EAG, Villanueva R. 2007. Rearing of Octopus vulgaris paralarvae: present status, bottlenecks and trends. Aquaculture 266:1-15 DOI 10.1016/j.aquaculture.2007.02.019.

Jatta G. 1889. Elenco dei Cefalopodi delle "Vittor Pisani". Bollettino della Societa di Naturalisti in Napoli 3:63-67.

Jurado-Molina J. 2010. A Bayesian framework with implementation error to improve the management of the red octopus (Octopus maya) fishery off the Yucatán Peninsula. Ciencias Marinas 36:1-14 DOI 10.7773/cm.v36i1.1627.

Kalinowski ST. 2005. HP-rare: a computer program for performing rarefaction on measures of allelic diversity. Molecular Ecology Notes 5:187-189.

Kimura M. 1983. The neutral theory of molecular evolution. Cambridge: Cambridge University Press. 
Kopelman NM, Mayzel J, Jakobsson M, Rosenberg NA, Mayrose I. 2015. Clumpak: a program for identifying clustering modes and packaging population structure inferences across K. Molecular Ecology Resources 15:1179-1191 DOI 10.1111/1755-0998.12387.

Lankford RR. 1977. Coastal lagoons of mexico their origin and classification. In: Wiley M, ed. Estuarine processes. New York: Academic Press, 182-215.

Lavin MF, Marinone SG. 2003. An overview of the physical oceanography of the gulf of California. In: Velasco Fuentes OU, Sheinbaum J, Ochoa J, eds. Nonlinear processes in geophysical fluid dynamics. Dordrecht: Kluwer Academic Publishers, 173-204.

López-Rocha JA, Arellano-Martínez M, Ceballos-Vázquez BP, Velázquez-Abunader I, Castellanos-Martínez S, Torreblanca-Ramírez E. 2012. Use of length-frequency analysis for growth estimation of the California two-spotted octopus Octopus bimaculatus Verrill 1883 of the Gulf of California. Journal of Shellfish Research 31:1173-1181 DOI 10.2983/035.031.0428.

López-Uriarte E, Rios-Jara E. 2009. Reproductive biology of Octopus hubbsorum (Mollusca:Cephalopoda) along the central mexican Pacific coast. Bulletin of Marine Science 84:109-122.

López-Uriarte E, Ríos-Jara E, Pérez-Peña M. 2005. Range extension for Octopus hubbsorum (Cephalopoda: Octopodidae) in the Mexican Pacific. Bulletin of Marine Science 77:171-180.

Lutz RA, Voight JR. 1994. Close encounter in the deep. Nature 371:563-563 DOI 10.1038/371563a0.

Marinone SG. 2012. Seasonal surface connectivity in the Gulf of California. Estuarine Coastal and Shelf Science 100:133-141 DOI 10.1016/j.ecss.2012.01.003.

Marinone SG, Ulloa MJ, Pares-Sierra A, Lavin MF, Cudney-Bueno R. 2008. Connectivity in the northern Gulf of California from particle tracking in a three-dimensional numerical model. Journal of Marine Systems 71:149-158 DOI 10.1076/j.jmarsys.2007.06.005.

Marko PB, Lee SC, Rice AM, Gramling JM, Fitzhenry TM, McAlister JS, Harper GR, Moran AL. 2004. Fisheries: mislabelling of a depleted reef fish. Nature 430:309-310 DOI 10.1038/430309b.

Moreno-Báez M, Cudney-Bueno R, Orr BJ, Shaw WW, Pfister T, Torre-Cosio J, Loaiza R, Rojo M. 2012. Integrating the spatial and temporal dimensions of fishing activities for management in the northern Gulf of California, Mexico. Ocean \& Coastal Management 55:111-127 DOI 10.1016/j.ocecoaman.2011.10.001.

Munguia-Vega A, Jackson A, Marinone SG, Erisman B, Moreno-Baez M, Giron-Nava A, Pfister T, Aburto-Oropeza O, Torre J. 2014. Asymmetric connectivity of spawning aggregations of a commercially important marine fish using a multidisciplinary approach. PeerJ 2:e511 DOI 10.7717/peerj.511.

Munguía-Vega A, Sáenz-Arroyo A, Greenley AP, Espinoza-Montes JA, Palumbi SR, Rossetto M, Micheli F. 2015. Marine reserves help preserve genetic diversity after impacts derived from climate variability: lessons from the pink abalone in Baja California. Global Ecology and Conservation 4:264-276 DOI 10.1016/j.gecco.2015.07.005. 
Norman MD, Hochberg FG. 2005. The current state of octopus taxonomy. Phuket Marine Biological Center Research Bulletin 66:127-155.

Palumbi SR, Martin AP, Romano SL, McMillan WO, Stacey L, Grabowski G. 1991. The simple fool's guide to PCR. Honolulu: University of Hawaii, Department of Zoology Special Publication.

Pauly D, Christensen V, Guenette S, Pitcher TJ, Sumaila UR, Walters CJ, Watson R, Zeller D. 2002. Towards sustainability in world fisheries. Nature 418:689-695 DOI 10.1038/nature01017.

Peakall R, Smouse PE. 2012. GenAlEx 6.5: genetic analysis in Excel. Population genetic software for teaching and research—an update. Bioinformatics 28:2537-2539 DOI 10.1093/bioinformatics/bts460.

Perrier E, Rochebrune ATd. 1894. Sur octopus nouveau de la basse Californie, habitant les coquilles des Mollusques bivalves. Comptes Rendus des Seances de l'Academie des Sciences 118:770-773.

Pickford GE, MacConnaughey BH. 1949. The Octopus bimaculatus problem: a study in sibling species. New Haven: Yale University, Peabody Museum of Natural History.

Pritchard JK, Stephens M, Donnelly P. 2000. Inference of population structure using multilocus genotype data. Genetics 155:945-959.

Queller DC, Goodnight KF. 1989. Estimating relatedness using genetic-markers. Evolution 43:258-275 DOI 10.2307/2409206.

Raymond M, Rousset F. 1995. GENEPOP (Version 1.2): population genetics software for exact tests and ecumenicism. Journal of Heredity 86:248-249 DOI 10.1093/oxfordjournals.jhered.a111573.

Riginos C, Liggins L. 2013. Seascape genetics: populations, Individuals, and Genes Marooned and Adrift. Geography Compass 7:197-216 DOI 10.1111/gec3.12032.

Romiguier J, Gayral P, Ballenghien M, Bernard A, Cahais V, Chenuil A, Chiari Y, Dernat R, Duret L, Faivre N, Loire E, Lourenco JM, Nabholz B, Roux C, Tsagkogeorga G, Weber AA, Weinert LA, Belkhir K, Bierne N, Glemin S, Galtier N. 2014. Comparative population genomics in animals uncovers the determinants of genetic diversity. Nature 515:261-263 DOI 10.1038/nature13685.

Roper CFE, Sweeney MJ, Hochberg FG. 1995. Cefalópodos. In: Guía FAO para la identificación de especies para los fines de la pesca Pacífico Centro-Oriental. Rome: FAO, 305-353.

Sala E, Aburto-Oropeza O, Reza M, Paredes G, López-Lemus LG. 2004. Fishing down coastal food webs in the gulf of California. Fisheries 29:19-25 DOI 10.1577/1548-8446(2004)29[19:fdcfwi]2.0.co;2.

Selkoe KA, Gaggiotti OE, Bowen BW, Toonen RJ. 2014. Emergent patterns of population genetic structure for a coral reef community. Molecular Ecology 23:3064-3079 DOI 10.1111/mec.12804.

Selkoe KA, Toonen RJ. 2011. Marine connectivity: a new look at pelagic larval duration and genetic metrics of dispersal. Marine Ecology Progress Series 436:291-305 DOI 10.3354/meps09238. 
Shanks AL. 2009. Pelagic larval duration and dispersal distance revisited. Biological Bulletin 216:373-385 DOI 10.1086/BBLv216n3p373.

Sinn DL. 2008. Patterns of activity cycles in juvenile California two-spot octopuses (Octopus bimaculoides). American Malacological Bulletin 24:65-69 DOI 10.4003/0740-2783-24.1.65.

Tamura K, Stecher G, Peterson D, Filipski A, Kumar S. 2013. MEGA6: molecular evolutionary genetics analysis version 6.0. Molecular Biology and Evolution 30:2725-2729 DOI 10.1093/molbev/mst197.

Thiel M, Gutow L. 2005. The ecology of rafting in the marine environment. II. The rafting organisms and community. Oceanography and Marine Biology —an Annual Review 43:279-418 DOI 10.1201/9781420037449.

Van Oosterhout C, Hutchinson WF, Wills DPM, Shipley P. 2004. micro-checker: software for identifying and correcting genotyping errors in microsatellite data. Molecular Ecology Notes 4:535-538 DOI 10.1111/j.1471-8286.2004.00684.x.

Verrill AE. 1883. Descriptions of two species of Octopus from California. Cambridge: Bulletin of the Museum of Comparative Zoology at Harvard College, 117-124.

Villanueva R, Vidal EA, Fernandez-Alvarez FA, Nabhitabhata J. 2016. Early mode of life and hatchling size in cephalopod molluscs: influence on the species distributional ranges. PLOS ONE 11:e0165334 DOI 10.1371/journal.pone.0165334.

Villegas EJA, Ceballos-Vázquez BP, Markaida U, Abitia-Cárdenas A, MedinaLópez MA, Arellano-Martínez M. 2014. Diet of Octopus bimaculatus Verril, 1883 (Cephalopoda: Octopodidae) in Bahía De Los Ángeles, Gulf of California. Journal of Shellfish Research 33:305-314 DOI 10.2983/035.033.0129.

Voss GL, Solís-Ramírez M. 1966. Octopus maya, a new species from the Bay of Campeche, Mexico. Bulletin of Marine Science 16:615-625.

Watson R, Pauly D. 2001. Systematic distortion in world fisheries catch trends. Nature 414:534-536 DOI 10.1038/35107050. 